\title{
Ventilatory function in rubber processing workers: acute changes over the workshift
}

\author{
M GOVERNA, M COMAI, M VALENTINO, L ANTONICELLI, F RINALDI, \\ E PISANI
}

From the Department of Public Health, Occupational Health Branch, University of Ancona, Nuovo Ospedale Regionale, I 60020 Torrette Ancona, Italy

ABSTRACT When considering rubber tyre manufacturing from an occupational health viewpoint, three areas may be identified in which exposure to respirable materials are potentially harmful: the processing, curing, and talc areas. A study of the ventilatory function of the entire work force employed in the processing area in a rubber tyre manufacturing plant was undertaker to determine whether an acute reduction in lung function occurs over the course of their working shift (the plant worked a three shift system) and whether a chronic exposure to the occupational airborne contaminants causes permanent changes in lung function. The ventilatory function was measured at the worksite at the beginning and immediately after the end of the workshift. No evidence of chronic obstructive pulmonary disease was found and in most cases no significant decline in FEV $_{1}$ was observed. Only one of the 79 individuals showed a moderate obstruction, measured by the ratio $\mathrm{FEV}_{1} / \mathrm{FVC}$ which gave the value of 0.55 , with no variation over the shift. For non-smokers, the FVC, $\mathrm{FEV}_{1}$, and $\mathrm{FEF}_{25-75 \%}$ were lower in those exposed for more than five years than in those exposed for five years or less. A similar pattern was also observed in the FVC and FEV 1 of the smokers. None of these differences was statistically significant. Within each exposure group the pulmonary function of the smokers was lower than that of the non-smokers, but the only significant difference was found in the values of $\mathrm{FEF}_{25-75 \%}$. Only one man showed a decline in the FEV 1 /FVC ratio over the shift, but during each shift, a decrease in all the lung function tests was observed. The decrease was smallest during the first of the three shifts. These results are thought to support the hypothesis that there are acute adverse effects over an eight hour shift. Further investigations are needed to discover whether these acute changes in lung function result from a chemical stimulation or irritant receptors in the airways.

The rubber industries use a greater variety of chemicals than any other branch of industry. A recent survey of the use of additive chemicals in 38 rubber manufacturing establishments in Sweden showed that about 500 substances or products were used. ${ }^{1}$

When considering rubber tyre manufacturing from an occupational health viewpoint, three areas were identified in which exposure to respirable materials seemed potentially harmful: the processing, curing, and talc areas. ${ }^{2}$

The processing area is the site at which workers are exposed to many atmospheric contaminants. At this site the raw ingredients are weighed and then put into a large banbury for mixing and heating before being

Accepted 29 September 1986 milled to obtain a softened product with its characteristic plasticity and viscosity. ${ }^{3}$ Many compounds are added to the rubber during the production of a complete tyre. The ingredients are numerous and include primary and secondary accelerators, activators, antizonants, antioxidants, curing agents, fillers, pepticisers, plasticisers, protectives, reinforcing agents, and softeners. Most are in powder form and, at process temperatures, have enough vapour pressure to be liberated from the rubber matrix to be given off as fumes and vapours. Consequently, workers are exposed to various combinations of airborne contaminants.

Many of these ingredients are potential respiratory hazards with acute or chronic effects. They may be both bronchoirritants, predisposing workers to chronic obstructive airways disease, and sensitisers, 


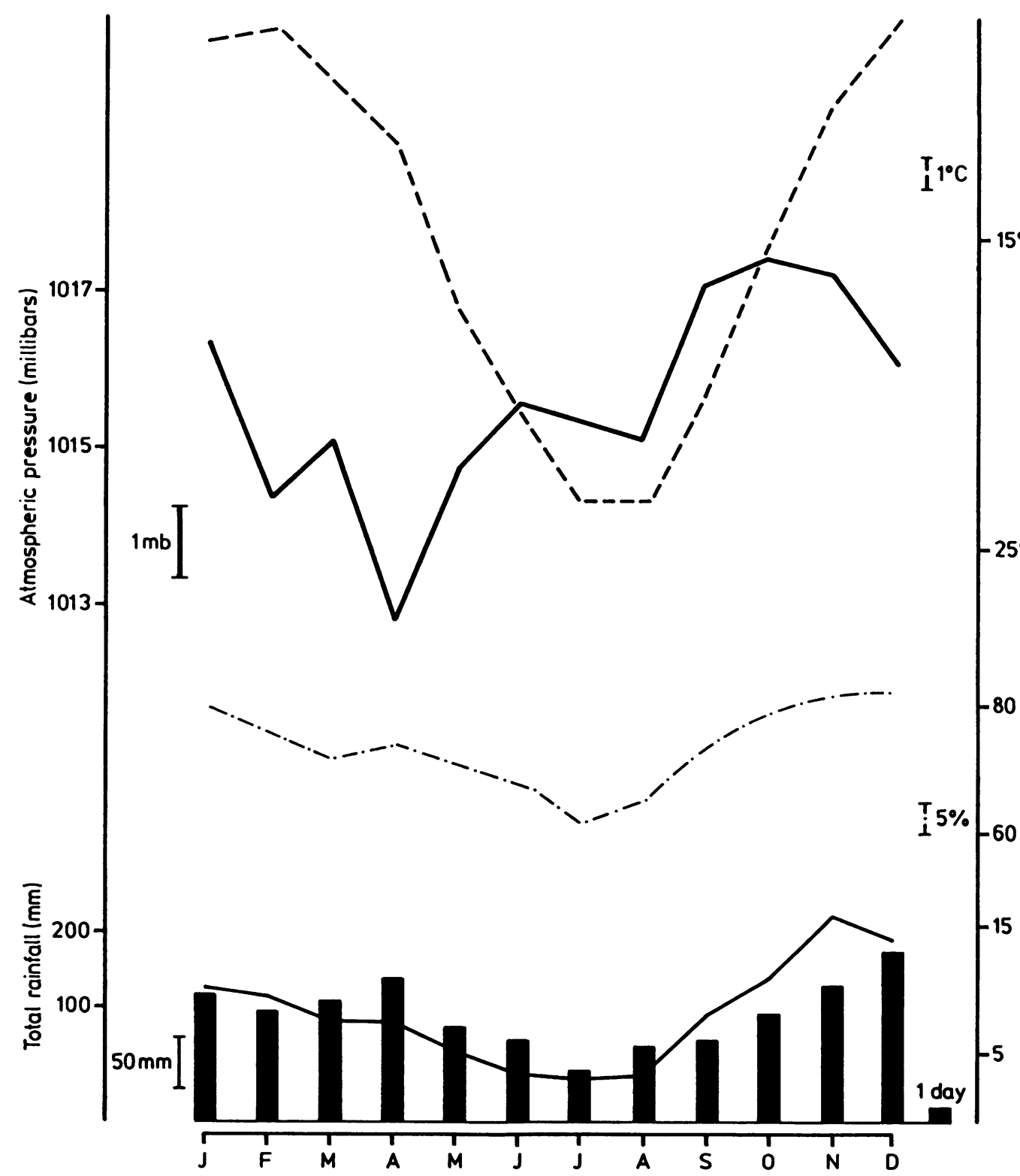

Climatic data for the district in which plant was built. Means of values collected from 1960 to 1979.

producing bronchial asthma. ${ }^{4-7}$

The ventilatory function of 79 of the 81 workers employed in a processing area in a rubber tyre manufacturing plant has been studied. The aim was to determine whether an acute reduction in lung function occurred over the course of the working shift and whether chronic exposure to the airborne contaminants in the processing area caused permanent changes in lung function.

\section{Material and methods}

The study was designed to include the entire work force employed in the processing area of a rubber tyre factory. The plant has been producing tyres since 1961 and was situated in the central part of Italy, in rural district, near the sea. Climatic data are sum marised in the figure.

In 1961 the industrial and urban development of 
this district was beginning and this process has continued at a moderate pace. A reasonable amount of historical data on the levels of atmospheric pollution were available and showed that there have been no hazard levels of air pollution from industrial or urban sources.

We considered our workers to be a homogeneous group in terms of environmental exposure, even though they have usually been grouped into three job categories (compounding, banbury mixing, and milling ${ }^{89}$ ) because the number of dust level records was insufficient to permit reliable and complete estimation of the exposure for each worker. Air samples were collected in 1979 using MSA portable pumps equipped with a cyclone filter in order to remove the non-respirable portion of the suspected particles with a Millipore PVC membrane filter ( $5 \mu \mathrm{m}$ pore). The mean dust levels were $1.90 \mathrm{mg} / \mathrm{m}^{3}, 2.20 \mathrm{mg} / \mathrm{m}^{3}$, and $2.85 \mathrm{mg} / \mathrm{m}^{3}$, respectively, for compounding, banbury mixing, and milling. Workers employed in preparing cements were excluded from the study because the cements were mixed in a completely separate area.

The medical history of each of the workers was collected and a thorough physical examination was performed. Each individual record card contained the following information: places of birth and residence, age, height, weight, smoking habits, and socioeconomic status. The subjects were classified according to their current smoking status as smokers of cigarettes or non-smokers. As the number of exsmokers was too small for valid statistical analysis they were added to the group of smokers; most had given up smoking in the preceding six months. There were no pipe or cigar smokers. A detailed occupational history was also taken: specific questions were asked concerning all the jobs held before and after employment at the plant under study. We were particularly interested in all previous occupations in high respiratory risk industries such as mining, tunnelling, quarrying, stone cutting or finishing, and sand blasting. Each worker was also asked whether he had worked in a foundry, pottery, refractory industry, abrasive and grinding wheel manufacture, or in a shipyard. Moreover, we asked the workers whether they had ever been employed in an asbestos textile plant or in any other plant entailing exposure to asbestos containing products.

Chest radiographs were obtained from the plant medical service and were carefully reviewed.

Ventilatory function was measured at work using the technique proposed by Horvath ${ }^{10}$ using a calibrated Vitalograph wedge bellows spirometer. This type of instrument had been used in recent studies on the ventilatory function of workers exposed to industrial air pollutants. ${ }^{11-15}$ The individuals were always tested by the same operator immediately before the beginning, and again immediately after, the end of the workshift. The plant worked a three shift system; the early shift lasted from 0600 to 1400 , the late shift from 1400 to 2200 , and the night shift from 2200 to 0600 . Tests were performed on the second and third day of the workweek; however, some men from the fourth morning day shift were also tested. The workers usually changed shifts at weekly intervals. They were tested only during the shift on which they were working at the time of study. Thirty men from the early shift, 24 men from the late shift, and 23 from the night shift were examined during a period of three weeks in the spring of 1979 .

The smokers were asked not to smoke for two hours before the test and each subject was trained until he was familiar with the manoeuvres. Before the test he rested in a sitting position for about 15 minutes. He was then asked to stand in front of the spirometer, as comfortably as possible, and a nose clip was put on. Results were registered until two satisfactory forced expiratory curves were obtained in which the best two readings of $\mathrm{FVC}, \mathrm{FEV}_{1}$, and FEF $_{25-75 \%}$ were within $50 \mathrm{ml}$ of each other. All the trails obtained were analysed by the same operator. In the analysis the highest FVC, $\mathrm{FEV}_{1}$, and $\mathrm{FEF}_{25-75 \%}$ values were taken and converted according to BTPS and the FEV 1 to FVC ratio was calculated. The standard equations of Morris et al ${ }^{16}$ were used to calculate the expected lung values and results were considered to be abnormal when they were below $70 \%$ of these expected values.

Seventy nine of the 81 workmen were studied; one man was absent during the study period and another was unable to perform the respiratory tests.

Preliminary studies were carried out on the same subjects to collect data on intersubject and intrasubject variability. The coefficient of intersubject variation was $1 \cdot 2 \%, 2 \cdot 1 \%$, and $3.6 \%$ for FVC, FEV 1 , and $\mathrm{FEF}_{25-75 \%}$, respectively. Data analysis was performed using standard statistical techniques. ${ }^{17}$

\section{Results}

Few of the subjects had been exposed to known occupational respiratory hazards before they were employed by the rubber company and none had worked in other areas of the plant or in other rubber factories. Since there were practically no differences in the ethnic and socioeconomics factors, we shall not consider them further. The $x$ ray film findings were also unremarkable and therefore they will not be discussed further either.

The most important demographic characteristics, age, height, smoking habits, and duration of employment in the processing area, of the survey population are shown in tables 1 and 2; their smoking habits and 
Table 1 Characteristics of the survey population $(n=79)$

\begin{tabular}{lr}
\hline Age (years): & \\
Mean & $40 \cdot 3$ \\
Standard deviation & $6 \cdot 6$ \\
Height (cm): & $170 \cdot 7$ \\
Mean & $5 \cdot 8$ \\
Standard deviation & 60 \\
Smoking habits: & 19 \\
$\quad$ Smokers & \\
$\quad$ Non-smokers & $6 \cdot 7$ \\
Duration of employment in the processing & 3.6 \\
area (years): & \\
Mean & \\
Standard deviation & \\
\hline
\end{tabular}

Table 2 Years of exposure in the processing area $(n=79)$

\begin{tabular}{lc}
\hline Years & No \\
\hline$\leqslant 5$ & 31 \\
$6-10$ & 35 \\
$11-15$ & 9 \\
$>15$ & 4 \\
\hline
\end{tabular}

Table 3 Smoking habits of the survey population

\begin{tabular}{lcc}
\hline & $\begin{array}{c}\text { Smokers } \\
(n=60)\end{array}$ & $\begin{array}{l}\text { Non-smokers } \\
(n=19)\end{array}$ \\
\hline $\begin{array}{l}\text { Age (years): } \\
\text { Mean }\end{array}$ & $40 \cdot 1$ & $40 \cdot 4$ \\
$\quad \begin{array}{l}\text { Standard deviation } \\
\text { Height (cm): }\end{array}$ & $7 \cdot 0$ & $5 \cdot 6$ \\
$\quad$ Mean & $171 \cdot 0$ & $169 \cdot 7$ \\
$\quad$ Standard deviation & $6 \cdot 0$ & $5 \cdot 6$ \\
No of years exposed in processing area: & 25 & 6 \\
$\quad \leqslant 5$ & 35 & 13 \\
$>5$ & & \\
\hline
\end{tabular}

Table 4 Duration of exposure of survey population

\begin{tabular}{lcc}
\hline & $\begin{array}{c}\text { Exposed } \\
\leqslant 5 \text { years } \\
(n=31)\end{array}$ & $\begin{array}{c}\text { Exposed } \\
>5 \text { years } \\
(n=48)\end{array}$ \\
\hline Age (years): & & \\
Mean & $39 \cdot 7$ & 40.5 \\
Standard deviation & $7 \cdot 1$ & $6 \cdot 3$ \\
Height (cm): & $168 \cdot 1$ & $172 \cdot 1$ \\
$\quad$ Mean & $5 \cdot 4$ & $5 \cdot 7$ \\
Standard deviation & 25 & 35 \\
Smoking habits: & 6 & 13 \\
$\quad$ Smokers & & \\
Non-smokers & & \\
\hline
\end{tabular}

duration of exposure are shown in tables 3 and 4.

Abnormal lung function was found in only two cases. A 43 year old man, a smoker, who had worked for nine years as a milling operator, had a $\mathrm{FEV}_{1} / \mathrm{FVC}$ ratio of 0.55 at the beginning and at the end of the shift. A 39 year old man, a smoker, who had worked for four years as a compounder had an $\mathrm{FEV}_{1} / \mathrm{FVC}$ ratio of 0.74 at the beginning and 0.59 at the end of the shift.
The mean values of FVC, $\mathrm{FEV}_{1}$, and $\mathrm{FEF}_{25-750}$ were analysed for changes over the shift; as is clearly? shown in table 5 , the means at the end of the shif were lower than at the beginning for each of the three. shifts. All the differences were statistically significan $(p \leqslant 0.01)$ except for the $\mathrm{FEV}_{1}$ values of the night? shift (table 6).

Comparison of the results in smokers and non $\frac{\overline{\bar{c}}}{\mathrm{~s}}$ smokers, and in the groups having less or more thap five years exposure, respectively, showed n® significant differences.

As already mentioned, the respiratory tests wers carried out on Tuesdays and Wednesdays. Control tests carried out on other working days showed n⿳亠े significant difference from the pattern obtained or Tuesdays and Wednesdays.

As may be seen in tables 7 and 8 , the only statisti cally significant difference between the smokers and non-smokers was in the decrease of the $\mathrm{FEF}_{25}-75 \%$ immediately before and after the shift. The smokers who had been exposed had a greater reduction if $\mathrm{FEV}_{25-75 \%}$ at the beginning and end of the shift than non-smokers irrespective of the duration of exposurge日 (table 9).

Within the group of non-smokers and the group on smokers the FVC and FEV 1 of those exposed for more than five years were reduced to a greater degrees than those exposed for less than five years; nongof these differences was statistically significant.

\section{Discussion}

In our investigation we found no evidence of chronio obstructive pulmonary disease and in most of the sub jects no significant decline in $\mathrm{FEV}_{1}$ was observed Only one of the 79 individuals showed moderate obstruction, as measured by the $\mathrm{FEV}_{1} / \mathrm{FVC}$ ratiof which was 0.55 ; there was no variation over the shift. Previous studies have shown that rubber processing workers with an exposure period of over 10 years ha $\bar{\phi}$ a significant decrease of the ratio $\mathrm{FEV}_{1} / \mathrm{FVC}$ com pared with the controls. ${ }^{18}{ }^{19}$ In our study only nine of the 79 subjects had been employed for more than 19 years in the processing area so the lack of evidence of chronic obstructive disease did not surprise us because of the relative smallness of this group.

Measurement of lung function before and after working shift forms the basis of testing for occupational asthma. In our study only one man showed a decline in the $\mathrm{FEV}_{1} / \mathrm{FVC}$ ratio over the shift. This might point to a low incidence of sympos tomatic asthma, but we have to take into account the possibility of a selective process by which asthma subo jects are removed from this type of worksite at an early stage in their disease and therefore before the period of our study. 
Table 5 Ventilatory function on each of the three workshifts

\begin{tabular}{|c|c|c|c|c|c|c|}
\hline & \multicolumn{2}{|c|}{ Early shift $(n=30)$} & \multicolumn{2}{|c|}{ Late shift $(n=29)$} & \multicolumn{2}{|c|}{ Night shift $(n=18)$} \\
\hline & Beginning & End & Beginning & End & Beginning & End \\
\hline \multicolumn{7}{|l|}{ FVC (l): } \\
\hline $\begin{array}{l}\text { Mean } \\
\text { Standard deviation }\end{array}$ & $\begin{array}{l}5.13 \\
0.63\end{array}$ & $\begin{array}{l}4.94 \\
0.72\end{array}$ & $\begin{array}{r}5 \cdot 30 \\
0.69\end{array}$ & $\begin{array}{r}4.70 \\
0.78\end{array}$ & $\begin{array}{l}4 \cdot 82 \\
0.70\end{array}$ & $\begin{array}{l}4.36 \\
0.65\end{array}$ \\
\hline \multicolumn{7}{|l|}{$\mathrm{FEV}_{1}(\mathrm{l})$ : } \\
\hline $\begin{array}{l}\text { Mean } \\
\text { Standard deviation }\end{array}$ & $4 \cdot 18$ & 4.04 & $4 \cdot 39$ & $3 \cdot 82$ & 3.91 & $3 \cdot 82$ \\
\hline \multicolumn{7}{|l|}{ FEF $(1 / s)$} \\
\hline Mean & 3.91 & 3.81 & 3.93 & $3 \cdot 37$ & $3 \cdot 50$ & 3.00 \\
\hline Standard deviation & 0.23 & 0.25 & $0 \cdot 37$ & $0 \cdot 28$ & $0 \cdot 26$ & $0 \cdot 19$ \\
\hline
\end{tabular}

Table 6 Changes in ventilatory function on each of the workshifts, preshift readings subtracted from postshift

\begin{tabular}{lccc}
\hline & Early shift $(n=30)$ & Late shift $(n=29)$ & Night shift $(n=18)$ \\
\hline FVC (l): & & & -0.528 \\
Mean differences & -0.171 & -0.689 & 0.343 \\
SD of differences & 0.216 & 0.521 & $6.530^{*}$ \\
$t$ & $6.980^{*}$ & $7.121^{*}$ & -0.092 \\
FEV (l): & -0.144 & -0.587 & 0.190 \\
Mean differences & 0.270 & 0.464 & 2.050 \\
SD of differences & $4.621^{*}$ & $6.812^{*}$ & -0.588 \\
FE (1/s): & -0.250 & -0.658 & 0.366 \\
Mean differences & 0.460 & 0.506 & $6.816^{*}$ \\
SD of differences & $4.397^{*}$ & $7.002^{*}$ & \\
\hline
\end{tabular}

SD = Standard deviation.

$t=$ Student's test for paired samples.

*Significant at the $1 \%$ level.

Table 7 Ventilatory function by duration of exposure

\begin{tabular}{|c|c|c|c|}
\hline & Exposed $\leqslant 5 y$ & Exposed $>5 y$ & \\
\hline Ventilatory function & $(n=30)$ & $(n=47)$ & $t$ \\
\hline $\begin{array}{l}\text { FVC (\% predicted): } \\
\text { Beginning of shift } \\
\text { End of shift }\end{array}$ & $\begin{array}{l}111 \pm 14 \\
106 \pm 14\end{array}$ & $\begin{array}{l}104 \pm 14 \\
100 \pm 14\end{array}$ & $\begin{array}{l}\text { NS } \\
\text { NS }\end{array}$ \\
\hline $\begin{array}{l}\mathrm{FEV}_{1}(\% \text { predicted }): \\
\text { Beginning of shift } \\
\text { End of shift }\end{array}$ & $\begin{array}{l}111 \pm 18 \\
107 \pm 18\end{array}$ & $\begin{array}{l}108 \pm 19 \\
104 \pm 17\end{array}$ & $\begin{array}{l}\text { NS } \\
\text { NS }\end{array}$ \\
\hline $\begin{array}{l}\text { FEF }_{2 s-75 \%}(\% \text { predicted }) \text { : } \\
\text { Beginning of shift } \\
\text { End of shift }\end{array}$ & $\begin{array}{l}97 \pm 29 \\
90 \pm 27\end{array}$ & $\begin{array}{l}89 \pm 30 \\
82 \pm 29\end{array}$ & $\begin{array}{l}\text { NS } \\
\text { NS }\end{array}$ \\
\hline
\end{tabular}

The ventilatory functions are given as mean percentage differences $( \pm \mathrm{SD})$ from the predicted according to Morris et al. ${ }^{6}$

$t=$ Student's independent $t$ test.
Previous studies on other workers have shown a circadian variation in ventilatory capacity in shift workers. ${ }^{2021}$ In our study we observed a decrease in all the lung function tests during each shift. The decrease was smaller during the early shift than during the two other shifts. From our preliminary data we can predict that, in a challenge test where the individual is used as his own control, a change of $1.3 \%$, $1.8 \%$, and $2.8 \%$ in the initial values of FVC, FEV and $\mathrm{FEF}_{25-75 \%}$, respectively, permits us to say with confidence that it was the challenge that caused the variation. Since any difference between the mean values measured at the beginning and the end of the shift was greater than the intrasubject variability, these

Table 8 Ventilatory function in smokers and non-smokers

\begin{tabular}{|c|c|c|c|}
\hline Ventilatory function & Smokers $(n=58)$ & Non-smokers $(n=19)$ & $t$ \\
\hline \multicolumn{4}{|l|}{ FVC (\% predicted): } \\
\hline $\begin{array}{l}\text { Beginning of shift } \\
\text { End of shift }\end{array}$ & $\begin{array}{l}105 \cdot 9 \pm 14 \cdot 8 \\
101 \cdot 9 \pm 14 \cdot 4\end{array}$ & $\begin{array}{l}108 \cdot 3 \pm 14 \cdot 4 \\
104 \cdot 9 \pm 12 \cdot 7\end{array}$ & $\begin{array}{l}-0.54 \text { (NS) } \\
-0.71 \text { (NS) }\end{array}$ \\
\hline \multicolumn{4}{|l|}{$\mathrm{FEV}_{1}$ (\% predicted): } \\
\hline $\begin{array}{l}\text { Beginning of shift } \\
\text { End of shift }\end{array}$ & $\begin{array}{l}106 \cdot 6 \pm 18 \cdot 6 \\
103 \cdot 1 \pm 17 \cdot 3\end{array}$ & $\begin{array}{l}116 \cdot 3 \pm 17 \cdot 7 \\
112 \cdot 3 \pm 17 \cdot 3\end{array}$ & $\begin{array}{l}-1.76 \text { (NS) } \\
-1.77 \text { (NS) }\end{array}$ \\
\hline \multirow{2}{*}{$\begin{array}{l}\text { FEF } 25-75 \% \text { (\% predicted): } \\
\text { Beginning of shift } \\
\text { End of shift }\end{array}$} & & & \\
\hline & $\begin{array}{l}86 \cdot 8 \pm 26 \cdot 9 \\
80 \cdot 5 \pm 24 \cdot 9\end{array}$ & $\begin{array}{l}115 \cdot 8 \pm 27 \cdot 6 \\
107 \cdot 1 \pm 24 \cdot 9\end{array}$ & $\begin{array}{l}-3 \cdot 73^{*} \\
-3 \cdot 50^{*}\end{array}$ \\
\hline
\end{tabular}

$t=$ Student's independent $t$ test.

*Significant at $1 \%$ level. 
Table 9 FEF of the smokers and non-smokers by duration of exposure

\begin{tabular}{|c|c|c|c|c|c|c|}
\hline Ventilatory function & $\leqslant 5$ yrs & & & $>5$ yrs & & \\
\hline $\begin{array}{l}\text { FEF }_{25-75 \%}(\% \text { predicted }): \\
\text { Beginning of shift } \\
\text { End of shift }\end{array}$ & $\begin{array}{l}\text { Smoker } \\
82 \cdot 4 \pm 24 \cdot 7 \\
75 \cdot 1 \pm 20 \cdot 6\end{array}$ & $\begin{array}{l}\text { Non-smoker } \\
128 \pm 35 \cdot 3 \\
122 \cdot 7 \pm 44 \cdot 1\end{array}$ & $\begin{array}{l}t \\
* \\
*\end{array}$ & $\begin{array}{l}\text { Smoker } \\
89 \cdot 9 \pm 28 \cdot 4 \\
84 \cdot 2 \pm 27 \cdot 2\end{array}$ & $\begin{array}{l}\text { Non-smoker } \\
112 \cdot 6 \pm 26 \cdot 2 \\
103 \cdot 2 \pm 22 \cdot 1\end{array}$ & $\begin{array}{l}t \\
* \\
*\end{array}$ \\
\hline
\end{tabular}

results are significant. These differences cannot be attributed to circadian variation: the lung capacity was also reduced on the early shift during which the circadian rhythm causes variations in the opposite direction..$^{20-22}$ These results are thought to support the hypothesis that there are acute adverse effects over an eight hour shift.

A decrement in ventilatory function over the workshift has been observed in workers exposed to other types of atmospheric contaminants, such as coal miners, ${ }^{23}$ cotton workers, ${ }^{24}$ and workers exposed simultaneously to jute and hemp, ${ }^{25}$ to chlorine and hydrochloric acid, ${ }^{26}$ and to benzene and benzaldehyde. ${ }^{26}$ We cannot identify the agent or agents affecting the lung of the rubber processing workers we examined because they have been exposed to a great variety of substances. While the lung function tests were being carried out, three or more compounding lines were simultaneously producing the different compounds needed for the manufacture of the several types of tyres made at the factory. It is impossible to investigate each of the numerous ingredients and the products resulting from their interaction.

To study the possibility of a chronic effect due to exposure at the work site, the results of the pulmonary function tests obtained at the beginning of each shift were compared with normal values. To consider the effect of tobacco, we preferred to use an equation derived from data from a population of healthy non-smokers than one derived from data from a population including smokers. For this reason we chose the equation of Morris et al ${ }^{16}$ rather than that of the European Coal and Steel Community, ${ }^{27}$ even though this may raise doubts about the validity of using predictive lung function equations from subjects living in another continent. The individuals examined by Morris et al ${ }^{16}$ had been exposed to relatively little atmospheric pollution, however, whereas those subjects studied by the CECA ${ }^{27}$ had been considerably exposed to occupational air contaminants; our workers were more like Morris's subjects in this respect.

Taking the non-smokers, the FVC, $\mathrm{FEV}_{1}$, and $\mathrm{FEF}_{25-75 \%}$ were smaller in those exposed for more than five years than in those exposed for five years or less. The same was true for the FVC and $\mathrm{FEV}_{1}$ in the smokers; none of these differences was statistically significant, however. Moreover, within each exposure group, the pulmonary function of the smokers was? lower than that of the non-smokers, but the only? significant difference was found for the $\mathrm{FEF}_{25-75 \%}$ values. None of the values, however, was ever below $70 \%$ of the predicted values so it seems logical to sup-ठ pose that no chronic lung damage has occurred in our 3 workers.

Other studies of pulmonary ventilatory capacity in rubber processing workers have been performed byo Osman et $l^{18}$ in Egypt and by Fine and Peters ${ }^{19}$ in the United States. Fine and Peters examined 52 work-? men, all smokers, selected from three tyre factories. $\vec{T}$ They concluded that exposure to airborne substancesi in the processing area affects pulmonary function and causes a decrease in the $\mathrm{FEV}_{1} / \mathrm{FVC}$ ratio and a drop in the value of $\mathrm{FEF}_{50}$. Abnormal values were recorded in 15 workers exposed for more than 1060 years (mean value 16.4 years), whereas the valigs measured in 37 workers exposed for less than 10 years (mean value 3.2 years) were not statistically different from the controls. These results are in good agree-ment with our findings since most of the workers weon studied had been exposed less than 10 years (mean value 6.8 years). To make a better comparison, how $\overrightarrow{\vec{B}}$ ever, a full knowledge of the climatic conditions tog which the American workers had been exposed would be required; unfortunately these data are lacking inộ. Fine's paper.

\section{References}

1 Holmberg B, Sjöström B. A toxicology survey of chemicals used in the Swedish rubber industry. Stockholm: National Board of Occupational Safety and Health, 1977. (Investigation repor No 19.)

2 Fine LJ, Peters JM. Respiratory morbidity in rubber workers. 음 Prevalence of respiratory symptoms and disease in curing workers. Arch Environ Health 1976;31:5-9.

3 Bebb RL. Chemistry of rubber processing and disposal. Environ Health Perspect 1976;17:95-101.

4 Weil E. Element de toxicologie industrielle. Paris: Masson, $1975^{\circ}$

5 Proctor NH, Hughes JP. Chemical hazards at the workplace. Phil adelphia: JB Lippincott Co, 1978.

6 do Pico GA. Occupational asthma. Advances in Asthma Allergy and Pulmonary Disease 1978;5:2-9.

7 Karr RM, Davies RJ, Butcher BT, et al. Occupational asthma. Allergy Clin Immunol 1978;61:54-65.

8 Gamble JF, Spirtas R. Job classification and utilization of com plete work histories in occupational epidemiology. J Occup Med 1976;18:339-404. 
9 Gamble JF, Spirtas R, Easter P. Applications of a job classification system in occupational epidemiology. Am J Public Health 1976;66:768-72.

10 Horvath EP. Proper training, technique vital to pulmonary testing. Occup Health Saf 1977;46:20-31

11 Burge PS, Perks W, O'Brien IM, Hawkins R, Green M. Occupational asthma in an electronics factory. Thorax 1979;34:13-8.

12 Baker MD, Irwing LM, Johnston JR, Turner DM, Bezuidenhout $B N$. Lung function in sisal ropemakers. $\mathrm{Br} J$ Ind Med 1979;36:216-9.

13 Chivers CP, Lawrence-Jones C, Paddle GM. Lung function in workers exposed to polyvinyl chloride dust. $\mathrm{Br} \mathrm{J}$ Ind $\mathrm{Med}$ 1980;37:147-51.

14 Lees $R$. Changes in lung function after exposure to vanadium compounds in fuel oil ash. Br J Ind Med 1980;37:253-6.

15 Kiviluoto $\mathrm{M}$. Observations on the lung of vanadium workers. $\mathrm{Br}$ J Ind Med 1980;37:363-6.

16 Morris JF, Koski A, Johnson LC. Spirometrics standards for healthy non-smoking adults. Am Rev Respir Dis 1971;103:57-67.

17 Armitage P. Statistical methods in medical research. New York: Wiley, 1971.

18 Osman HA, Wahdan MH, Noweir MH. Health problems resulting from prolonged exposure to chemical agents in rubber industry. J Egypt Public Health Assoc 1972;157:290-311.

19 Fine LJ, Peters JM. Studies of respiratory morbidity in rubber workers III. Respiratory morbidity in processing workers. Arch Environ Health 1976;31:136-40.

20 Guberan E, Williams MK, Walford J, Smith MM. Circadian variation of FEV in shift workers. Br J Ind Med 1969;26:121-5.

21 Walford J, Lammers B, Schilling RSF, Van der Hoven Van Genderen D, Van der Veen YG. Diurnal variation in ventilatory capacity. An epidemiology study of cotton and other factory workers employed on shift work. Br J Ind Med 1966;23:142-8.

22 Gaffuri E, Costa G. Ritmi circadiani degli indici spirometrici Rivista degli Infortuni e delle Malattie Professionali 1978;46:37-43.

23 Hankinson JL, Reger RB, Fairman RP, Lapp NL, Morgan WKC. Factors influencing expiratory flow rates in coal miner. In: Walton WH, ed. Inhaled particles IV. Part II. Oxford: Pergamon Press, 1977:737-58.

24 McKerrow CB, McDermott M, Gilson JC, Shilling RSP. Respiratory function during the day in cotton workers: a study in byssinosis. Br J Ind Med 1958;15:75-83.

$25 \mathrm{El}$ Ghawabi SH. Respiratory function and symptoms in workers exposed simultaneously to jute and hemp. Br J Ind Med 1978;35:16-20.

26 Dimich HD, Sterling TD. Ventilatory function changes over a workshift. Br J Ind Med 1981;38:152-5.

27 Promemoria tecnico per l'esame della funzione ventilatoria con la spirografia. 2nd ed. Luxemborg: Commission of the European Communities, CECA, 1971. (Industrial health and medicine series, No 11.)

\section{Destruction of manuscripts}

From 1 July 1985 articles submitted for publication will not be returned. Authors whose papers are rejected will be advised of the decision and the manuscripts will be kept under security for three months to deal with any inquiries and then destroyed. 